Available Online at ESci Journals

Journal of Plant Breeding and Genetics

ISSN: 2305-297X (Online), 2308-121X (Print)

http://www.escijournals.net/JPBG

\title{
EVALUATION OF COWPEA (VIGNA UNGUICULATA) GENOTYPES FOR FODDER YIELD AND RESISTANCE AGAINST LEAF SPOT (PSEUDOCERCOSPORA CRUENTA)
}

\author{
Ahmad Hussain, Muhammad R. Gondal, Sikandar Hayat, Syed I. Yasin, Muhammad S. Hanif, \\ Ghulam Nabi, Muhammad S. Akhtar \\ Fodder Research Institute, Sargodha, Pakistan.
}

\section{A B S T R A C T}

Cowpea, Vigna unguiculata (L.), is an important grain legume grown in the tropics and constitutes a valuable source of protein in the diets of millions of people. Some abiotic and biotic stresses adversely affect its productivity. Among biotic factors, Pseudocercospora leaf spot is a widespread disease claim significant losses to the crop. Present studies consisted of two experiments, i.e., the pot experiment was carried out under glasshouse conditions and another experiment was conducted under field conditions. Eight local cowpea genotypes viz., CP-383, CP-162, CP-145, CP-271, CP-219, IT84-552, SS-92 and IT82E-715 were evaluated for yield parameters, green fodder yield and their reaction against Cercospora leaf spot disease compared with the commercially approved variety 'Rawan 2003 ' for two 'Kharif seasons. The lowest disease index (2.76 \%) was recorded in CP-383 followed by statistically similar resistance shown by check variety, CP 2003 (4.07\%) and CP-219 (4.53\%). The highest susceptibility with disease index (18.32\%) was exhibited by IT84-552. The genotypes differed significantly on the basis of length, thickness and branching of vines, number and size of their leaves. The accession CP-383 out-performed the other accession lines in green fodder yield during both the years and can be ranked as the best gene resources for future breeding programmes.

Keywords: Cowpea, Cercospora Leaf Spot, Pseudocercospora Fodder Yield.

\section{INTRODUCTION}

Catering for the nutritional requirements of the livestock and dairy animals fodder production plays an important and pivotal role in the livestock industry. There is a continuous need for an increase in the milk and meat production of the country to meet the requirements of ever increasing population. Although, maize and sorghum are more common 'Kharif season fodder crops the need for other crops, to meet the nutritional requirements of the livestock and dairy animals bears great importance. The livestock and dairy animals require a higher percentage of protein in their fodder to produce meat and milk. Cowpea (Vigna unguiculata), a kind of legume is a Kharif season crop cultivated on a smaller area in the country and availability of literature regarding the fodder crop of cowpea is scanty (Khan et al., 2010). The cowpea crop, despite having a lesser area under cultivation for the production of fodder, cannot be

* Corresponding Author:

Email: frisikandar@gmail.com

(C) 2019 ESci Journals Publishing. All rights reserved. undermined due to the higher nutritional contents especially a higher crude protein percentage (Sebetha et al., 2010; Jackson, 2009) are relatively higher than the other 'Kharif season fodder crops. The inclusion of the crop in the regular cropping schemes and crop rotation contributes towards the fertility enhancement of agricultural lands due to its leguminous nature the capacity of fixing atmospheric nitrogen through the nodules (Hayat et al., 2008). Hence, cowpea fodder crop is considered as an excellent source of protein supplement for the dairy and livestock animals. Unfortunately, Rawan 2003 is the only commercial variety of cowpea available for cultivation in Punjab.

Cowpea crop is generally attacked by a fungal Pathogen, Cercospora cruenta or Mycosphaerella cruenta, producing leaf spots on the leaves. The same pathogen has been termed as Pseudocercospora cruenta (Sacc.) Deighton. Although the disease pathogen is synonymously mentioned as Cercospora cruenta (Sacc.) and Pseudocercospora cruenta (Sacc.) Deighton but there have been some characteristic symptomatic differences 
reported in case of the leaf spots caused by these two pathogens (Emechebe and Lagoke, 2003).

Cercospora leaf spot is a widespread disease that can claim significant losses to the crop (Fery and Dukes, 1977). C. apii s. lat has also been mentioned to be associated with the Cercospora leaf spot disease but with lesser significance (Booker and Umaharan, 2007). In some areas, the occurrence of the two pathogens has been identified and reported to have marked a difference in their disease expressions. Differential response of cowpea cultivars has been reported against infection by Pseudocercospora cruenta (Sacc.) Deighton, (Allard, 1999; Emechebe and Lagoke, 2003). Such differential behaviour of cowpea cultivars, against the disease, has been attributed due to the probable presence of more than one pair of resistance genes (Fery and Dukes, 1977; Allard et al., 1992; Booker, 2008). The same pathogen is responsible for attacking the barley crop (Allard et al., 1992).

The disease produces brown or rust coloured lesions that vary from circular to angular in shape. In some cases, the margin of the lesions is distinctly reddish. These lesions may vary from 2 to $10 \mathrm{~mm}$ across. The occurrence of the lesions is more common on the mature leaves. The older lesions develop a grey necrotic region in the centre of the lesions producing conidia in this part of the lesion. The lesions may coalesce to affecting a larger leaf area. Chlorosis of the leaves may also occur in severe infections.

The current study focuses on the possible introduction of new cowpea varieties that can give better fodder yield and have better resistance against Cercospora leaf spot. The lines that have high green fodder yield can be used for improving the fodder potential of the existing commercial variety. The current study was conducted to identify cowpea lines that are resistant against $P$. cruenta so that such lines may be used for developing resistance in the commercially available cowpea variety through genetic recombination.

\section{MATERIAL AND METHODS}

Present study investigation consisted of two experiments, i.e., the pot experiment that was carried out under glasshouse conditions and another experiment was conducted under field conditions. Eight selected lines of cowpea viz. CP-383, CP-162, CP-145, CP271, CP-219, IT84-552, SS-92 and IT82E-715 were tested for their field performance against the approved commercial variety 'Rawan 2003'. The studies on plant growth parameters were conducted at the experimental field area of Fodder Research Institute, Sargodha. The plant growth parameters included vine length $(\mathrm{cm})$, stem diameter $(\mathrm{mm})$, number of branches per plant, number of leaves per plant, and leaf area (sq. cm). The yield trials, focused at the green fodder yield, were carried out at three different locations during 'Kharif' seasons of 2016-17 \& 2017-18. Evaluation of the cowpea lines for their reaction against Cercospora leaf spot disease was carried out in pot studies conducted in the screen house. All the studies were conducted in triplicated experiments.

Culture Preparation: The cowpea lines were screened against Cercospora leaf spot in pot experiments conducted for two years of inoculated conditions. The culture of Cercospora cruenta was grown on potato carrot agar (PCA) at $25 \pm 2 \stackrel{\circ}{\circ}$ for three weeks. Water was poured on the medium to sweep off the spores and filtered through two layers a fine mesh muslin cloth. The concentration of spore suspension was maintained at 120 spores/ $\mathrm{ml}$ containing $0.1 \%$ Tween 20 to achieve better infection.

Pot Preparation and Sowing: Terracotta pots measuring $30 \mathrm{~cm}$ diameter were used for the study. Equal quantities of sand, silt and field soil, sieved through 25 mesh sieves, and sterilized were mixed and used for filling the pots. Watering of the pots was carried out thoroughly. Two to three seeds were sown at equally spaced four different points. After the emergence of the seedlings thinning was done to maintain a single plant at four points of each pot. An equal amount of water for each pot was given daily and regularly to maintain an adequate amount of moisture content in the growing medium of the pots.

Inoculation of Plants: Twenty-eight days after sowing, inoculation of spores of Pseudocercospora cruenta (Sacc.) Deighton was done by spraying $10 \mathrm{ml}$ inoculum suspension per plant on the second, third and fourth compound leaves followed by smearing it all over the leaves using a method described by Sinsiri et al. (2006). The concentration of the inoculum suspension was maintained at $5.0 \times 104 \mathrm{~mL}^{-1}$. Plastic bag measuring $40 \mathrm{~cm}$ wide and $120 \mathrm{~cm}$ length was punctured with a paper punching machine resulting in four holes, of $5 \mathrm{~mm}$ diameter, every $20 \mathrm{~cm}$ length of the tubular plastic bag. The entire plant was covered with the punctured bag while the open end of the bag was wrapped over the rim of the pot and tied with the help of a string. The covering 
of the plants in plastic bags was maintained for three days after inoculation to facilitate infection. The bags were untied three times a day, for an hour each time, to allow ventilation and avoid excessive condensation of water.

Disease Assessment: The observations on the incidence and severity of the disease were recorded starting from two weeks after inoculation on fortnightly basis. Observations on the severity were recorded on the basis of leaf spot rating scale as under:

\section{Leaf Spot disease rating scale}

$$
\begin{aligned}
& 0=\text { No leaf spots seen } \\
& 1=\text { Less than } 1 \% \text { of leaf area affected } \\
& 2=1-10 \% \text { leaf area affected } \\
& 3=11-25 \% \text { leaf area affected } \\
& 4=26-50 \% \text { leaf area affected } \\
& 5=51 \text { or more leaf area affected }
\end{aligned}
$$

The percentage of infection and the severity scores were used to calculate Disease Index (DI) following the Parry's adapted formula (Parry, 1990) detailed as under:

$$
\begin{gathered}
D I=[(0 \times a)+(1 \times b)+(2 \times c)+(3 \times d)+(4 \times e)+(5 \times f)] \\
/(a+b+c+d+e+f) \times 100 / 5
\end{gathered}
$$

Where $a, b, c, d$, e and $f$ are the number of plants with levels of infection equal to $0,1,2,3,4$ and 5 respectively.

Field Trials on Green Fodder Yield: The field trials were conducted during the 'Kharif season of 2016-17 and 2017-18 at the experimental fields of the Fodder Research Institute (FRI) Sargodha and the experimental fields of its sub-stations i.e., Experimental Seed Production Unit (ESPU), Farooqabad (district Sheikhupura) and Forage Production-Ayub Agricultural Research Institute (FP-AARI), Faisalabad (district Faisalabad). Sowing was done with drilling $40 \mathrm{~kg}$ seeds /ha. Each plot had six rows of 5 meter length, maintaining $50 \mathrm{~cm}$ row-to-row distance, resulting in $3 \mathrm{~m}$ X $5 \mathrm{~m}$ plot. Fertilizer NPK was added at the rate of 5057-0 kg/ha at all the locations. Any weeds appearing in the field were removed manually through hoeing. All the yield trials were conducted similarly at all the locations in Randomized Complete Block Design (RCBD) with four replications. Green fodder yield data were recorded at $5 \%$ pod formation.

The data recorded on all the growth parameters, disease index and green fodder yield were subjected Analysis of Variance (ANOVA) and the significance was tested using Statistix 8.1 analytical software copyright 1985-2005.

\section{RESULTS AND DISCUSSION}

The growth behaviour of different genotypes was studied and is briefed in the following lines.

Plant Growth Parameters: The lines exhibited significant differences in all the growth characteristics investigated during the study (Table 1, 2 \& 4). Cowpea line CP-383 had the maximum vine length $(347.5 \mathrm{~cm})$ and no other line had similar vine length (Table 1). The second group of the test lines with the longest vines, but significantly shorter than that of the line CP-383, included CP-162 and CP-145 with 322.9 and $318.5 \mathrm{~cm}$ vine length respectively. The rest of the lines could be statistically ranked in further different groups.

Stem diameter varied significantly among the genotypes. The accession lines CP-383 and CP-21 had the thickest stem or vine measuring 9.6 and $9.3 \mathrm{~mm}$ respectively against $6.4 \mathrm{~mm}$ thick diameter in the check variety (Table 1). The second group of genotypes, as regards the thickness of stem, included CP-162 and IT84-552 having 8.5 and $8.2 \mathrm{~mm}$ stem thickness respectively. The lankiest stems were recorded in case of IT82E-715 and the Check (CP-2003) having 6.3 and $6.4 \mathrm{~mm}$ respectively. The genotypes CP-145 and SS-92 were at par with the check variety for having 6.8 and $6.7 \mathrm{~mm}$ stem thickness.

The branching of vines also varied greatly among the genotypes and the differences were found to $b$ significantly different. Comparing the branching behaviour of the genotypes it was found that CP-383 had 4.8 mean for branching against 4.0 mean branching means in the Check. CP-162 and CP-145 could be placed in the second highest mean for stem branching having 4.6 and 4.5 branching mean respectively (Table 1 ). The genotypes IT84-552 and CP-219 were found to be at par with the Check as regards branching.

The main characteristic growth of the plants depends on the leaves. Plant biomass is the most valuable and highly weighing characteristic of a fodder crop for green fodder yield. The leaves have a direct relationship with the plant photosynthetic activity. Two parameters of leaves, the number of leaves per plant and the leaf area, were compared in the studies. The results revealed significant differences for both the parameters (Table 2). The highest number of leaves per plant (352.4) was recorded in CP-383 while the second highest level for a number of leaves per plant 312.5 and 302.5 was recorded in case of CP-162 and CP-145 respectively against 242.3 leaves per plant recorded in the Check variety. However, two genotypes CP-271 and CP-219 were found to be statistically similar to CP-145 for having 296.77 and 293.2 leaves per plant respectively (Table 2 ). 
Table 1. Vine length, stem thickness and number of branches of different cowpea lines/genotypes.

\begin{tabular}{ccccc}
\hline S. No. & Cowpea Lines/varieties & Vine Length $(\mathrm{cm})^{*}$ & Stem Diameter $(\mathrm{mm})^{*}$ & No. of Branches* \\
\hline 1 & CP-383 & $347.5_{a}$ & $9.6_{a}$ & $4.8_{a}$ \\
2 & CP-271 & $303.5_{c d}$ & $9.3_{a}$ & $4.2_{c}$ \\
3 & CP-162 & $322.9_{b}$ & $8.5_{b}$ & $4.6_{b}$ \\
4 & CP-145 & $318.5_{b c}$ & $6.8_{d}$ & $4.5_{b}$ \\
5 & IT84-552 & $229.3_{f}$ & $8.2_{b}$ & $4.0_{c d}$ \\
6 & CP-219 & $288.4_{d e}$ & $7.5_{c}$ & $4.1_{c d}$ \\
7 & Check (CP 2003) & $282.7_{e}$ & $6.4_{d e}$ & $4.0_{d}$ \\
8 & SS-92 & $213.6_{f}$ & $6.7_{d}$ & $3.8_{e}$ \\
9 & IT82E-715 & $217.9_{f}$ & $6.3_{e}$ & $3.5_{f}$ \\
\hline
\end{tabular}

${ }^{*}$ The means not sharing a letter in common are statistically different at $5 \%$ level.

Table 2. Number of leaves and leaf size of different cowpea lines/genotypes.

\begin{tabular}{cccc}
\hline S. No. & Cowpea Lines/varieties & No. of Leaves* & Leaf Area (sq. cm)* \\
\hline 1 & CP-383 & $352.4_{a}$ & $88.6_{b}$ \\
2 & CP-271 & $296.7_{c}$ & $102.9_{a}$ \\
3 & CP-162 & $312.5_{b}$ & $82.8_{c}$ \\
4 & CP-145 & $302.5_{b c}$ & $76.4_{d}$ \\
5 & IT84-552 & $248.6_{d}$ & $83.0_{c}$ \\
6 & CP-219 & $293.2_{c}$ & $69.8_{e f}$ \\
7 & Check (CP 2003) & $242.3_{d e}$ & $73.9_{d e}$ \\
8 & SS-92 & $240.4_{d e}$ & $61.3_{g}$ \\
9 & IT82E-715 & $232.6_{e}$ & $66.0_{f g}$ \\
\hline
\end{tabular}

*The means not sharing a letter in common are statistically different at 5\% level.

The lines/genotypes were tested for their reaction against Cercospora leaf spot disease. Observations on the disease were recorded in the form of disease incidence and severity. There was no relationship of incidence of the disease with its severity for a given cultivar or accession. The two parameters behaved independently of each other and were suggested to be discussed directly in the present study whereas the combined effect of the two parameters, the disease index, was investigated.

The collection of the cowpea genotypes displayed a differential behaviour in response to the Cercospora leaf spot disease and a range of behaviour on incidence and the severity was recorded in case of the tested genotypes. Significant differences among the disease indices were recorded in case of these cultivars. Such a differential behavior to Cercospora leaf spot disease is indicative of multiple gene pair for the disease in the cowpea crop (Allard, 1999; Emechebe and Lagoke, 2003). Similar findings against Cercospora leaf spot disease have been reported in barley crop as well (Allard et al., 1992).

Significant differences in the reaction of the genotypes to the disease were recorded (Table 3). The lowest disease index (2.76 \%) was recorded in case of the accession CP383 followed by statistically similar resistance shown by Check variety (CP 2003) and CP-219 having with 4.07 and $4.53 \%$ disease index respectively. The cultivar CP145 was found at par with the Check variety with $6.01 \%$ disease index. The highest susceptibility to the disease was exhibited by the cultivar IT84-552 with 18.32\% disease index. In the current studies, several cowpea cultivars has shown a good level of resistance to Cercospora leaf spot that confirms the studies of Sinsiri et al. (2006).

Looking at the studies conducted on green fodder yield at Fodder Research Institute, Sargodha individually, it was revealed that CP-383 had the best performance as regards green fodder yield (45.94 t/ha) followed by statistically similar CP-271, CP-162 \& CP-145 yielding 45.07, 44.69 \& 44.05 t/ha green fodder yield, respectively. All these varieties significantly outperformed the Check variety (CP 2003) as regards green fodder yield. All the other genotypes were statistically at par with the Check variety. 
Table 3. Disease reaction of cowpea lines/varieties against Cercospora leaf spot disease.

\begin{tabular}{clc}
\hline S. No. & \multicolumn{1}{c}{$\begin{array}{c}\text { Cowpea } \\
\text { Lines/varieties }\end{array}$} & $\begin{array}{c}\text { Leaf Spot Disease } \\
\text { Index (\%)* }\end{array}$ \\
\hline 1 & CP-383 & $2.76_{f}$ \\
2 & Check (CP 2003) & $4.07_{e f}$ \\
3 & CP-219 & $4.53_{e f}$ \\
4 & CP-145 & $6.01_{d e}$ \\
5 & IT82E-715 & $7.66_{d}$ \\
6 & CP-162 & $10.03_{c}$ \\
7 & SS-92 & $11.25_{c}$ \\
8 & CP-271 & $15.55_{b}$ \\
9 & IT84-552 & $18.32_{a}$ \\
\hline
\end{tabular}

*The means not sharing a letter in common are statistically different at $5 \%$ level.

While looking at the individual results of green fodder yield studies conducted at Experimental Seed Production Unit, Farooqabad, it was recorded that CP383 gave the highest (48.90 t/ha) green fodder yield followed by statistically similar yield (48.30 t/ha) by the cultivar CP-271. The cultivar CP-162 also outyielded the Check variety by yielding $47.57 \mathrm{t} / \mathrm{ha}$ green fodder. Green fodder yield in case of CP-162 was statistically equal to CP-271 but significantly lower than the best yield variety (CP-383), as regards the green fodder yield.

The studies conducted on green fodder yield at the third location, Forage Production-AARI, Faisalabad, it was recorded that $\mathrm{CP}-383$ yielded the maximum green fodder yield ( $51.23 \mathrm{t} / \mathrm{ha}$ ) followed by statistically similar two cultivars CP-271 \& CP-162 yielding 48.89 and 48.51 t/ha respectively. Three other cultivars viz., IT84-552, CP-145, and CP-219 yielded 46.32, 45.96 \& 45.62 t/ha green fodder yield but were statistically at par with the Check yielding $44.16 \mathrm{t} /$ ha green fodder.

The overall studies, conducted at three different stations, revealed that two cowpea lines CP-383 and CP271 gave the highest green fodder yield, 48.69 and 47.42 t/ha green fodder yield, closely followed by a line CP162 yielding $46.93 \mathrm{t} /$ ha green fodder yield against 41.14 t/ha green fodder yield by the check variety (Table 4). The cultivars CP-383, CP-271 and CP-162 yielded 18.35, 15.26 and $14.07 \%$ higher fodder yield respectively than the Check variety.

Studying the interaction points, between the genotypes and the locations (Table 5), it was found that the best performance of all the varieties was recorded at the FP-
AARI, Faisalabad, followed by ESPU, Farooqabad and FRI, Sargodha in the decreasing trend. The interaction effect of the genotypes and locations, as measured with the yield, reflects either the climatic difference or the fertility difference among the locations as discusses by Qamar et al. (1993). Green fodder yield data recorded at FP-AARI, Faisalabad revealed that three varieties CP383, CP-271 and CP-162 were the best performers as regards green fodder yield. The cultivars yielded 51.23, 48.89 and $48.51 \mathrm{t} / \mathrm{ha}$ green fodder yield against 41.14 t/ha green fodder yield by the Check (CP 2003). The differences in the fodder yield and other parameters of the yield may be attributed to genotypic variation and environmental interaction (Qamar et al., 1993).

Considering the circumstances of increased nutritional demands of the livestock and dairy animals there is a need for developing or introducing high yielding fodder varieties. The development and release of new fodder varieties remain a prime agenda of the plant breeders and to achieve the goal they constantly need new genetic input in their gene banks that have stable yield across a larger area (Sabaghnia et al., 2006). The current study has identified a higher fodder yield potential in some cultivars. These cultivars can be included in the breeding programme for developing high fodder yielding varieties through hybridization.

Studies on the assessment of disease resistance genes against Cercospora leaf spot have indicated the presence of multiple genes for resistance against the disease (Fery and Dukes, 1977; Fery et al., 1976). The current study indicates a high level of resistance to leaf spot disease in some cultivars that can be used in hybridization for resistance in the earlier studies. The current studies have identified a high level of resistance against Cercospora leaf spot in some cultivars. These cultivars may be used in hybridization programme for developing resistance in the existing commercial variety.

Looking at the overall outcome of the multi-location trials conducted for two years for assessment of green fodder yield potential of cowpea cultivars it was found that CP-383, CP-271 CP-162, CP-145, IT84-552 and CP219 have performed consistently well at the three locations (Table 5). The genotypes have shown a desirable genotypic trait in the form of stability in yield as reflected by their interaction with the different environment or locations as mentioned by Sabaghnia et al. (2006). The yield potential of these genotypes was better or comparable to the Check variety (CP 2003). 
Table 4. Comparison of cowpea lines/varieties for fresh fodder yield.

\begin{tabular}{clc}
\hline S. No. & \multicolumn{1}{c}{$\begin{array}{c}\text { Cowpea } \\
\text { Lines/varieties }\end{array}$} & $\begin{array}{c}\text { Mean Fresh Fodder } \\
\text { Yield (t/ha)* }\end{array}$ \\
\hline 1 & CP-383 & $48.69_{a}$ \\
2 & CP-271 & $47.42_{a b}$ \\
3 & CP-162 & $46.93_{b c}$ \\
4 & CP-145 & $45.28_{c d}$ \\
5 & IT84-552 & $44.96_{d}$ \\
6 & CP-219 & $42.81_{e}$ \\
7 & Check (CP 2003) & $41.14_{f}$ \\
8 & SS-92 & $39.87_{f}$ \\
9 & IT82E-715 & $40.62_{f}$ \\
\hline
\end{tabular}

*The means not sharing a letter in common are

statistically different at $5 \%$ level.
Similarly, looking at the results of the screening against Cercospora leaf spot under inoculated conditions, CP383 has performed better than, while CP-219 has performed equivalent to, the Check variety (CP 2003). The results of the current study (Table 3, 4 \& 5) suggest that the cultivar CP-383 and CP-219 have the potential for consideration as a candidate variety for general cultivation in the Punjab province of Pakistan.

Table 5. Comparison of cowpea lines/varieties for green fodder yield at different locations

\begin{tabular}{llccc}
\hline \multirow{2}{*}{ S. No. } & \multicolumn{1}{c}{ Cowpea } & \multicolumn{2}{c}{ Green Fodder Yield (t/ha) at different Locations* } \\
\cline { 3 - 5 } & \multicolumn{1}{c}{ Lines/varieties } & FRI, Sargodha & ESPU, Farooqabad & FP-AARI, Faisalabad \\
\hline 1 & CP-383 & $45.94_{\text {cdef }}$ & $48.90_{a b}$ & $51.23_{a}$ \\
2 & CP-271 & $45.07_{\text {efgh }}$ & $48.30_{b c d}$ & $48.89_{a b}$ \\
3 & CP-162 & $44.69_{f g h}$ & $47.57_{c d e}$ & $48.51_{a b c}$ \\
4 & CP-145 & $44.05_{\text {fghij }}$ & $45.82_{\text {cdefg }}$ & $45.96_{c d e f}$ \\
5 & IT84-552 & $42.62_{h i j}$ & $45.93_{\text {cdef }}$ & $46.32_{b c d e f}$ \\
6 & CP-219 & $39.10_{k l}$ & $43.70_{\text {fghij }}$ & $45.62_{\text {defg }}$ \\
7 & Check (CP 2003) & $36.28_{l m}$ & $42.97_{\text {ghij }}$ & $44.16_{f g h i}$ \\
8 & SS-92 & $35.44_{m}$ & $41.78_{i j k}$ & $42.39_{h i j}$ \\
9 & IT82E-715 & $36.82_{l m}$ & $41.26_{j k}$ & $43.77_{f g h i j}$ \\
\hline
\end{tabular}

*The means not sharing a letter in common are statistically different at $5 \%$ level.

\section{REFERENCES}

Allard, R. W. 1999. Principles of Plant Breeding John Wiley and Sons: New York, USA.

Allard, R. W., Q. I. F. A. Zhang, M. A. Maroof and O. M. Muona. 1992. Evolution of multilocus genetic structure in an experimental barley population. Genetics, 131: 957-69.

Booker, H. M. 2008. Studies on resistance to cercospora leaf spot (CLS) disease and the impact of CLS and cowpea severe mosaic virus (CPSMV) diseases on productivity of vigna unguiculata (L.) Walp. in Trinidad, The University of the West Indies.

Booker, H. M. and P. Umaharan. 2007. Identification of resistance to Cercospora leaf spot of cowpea. European Journal of Plant Pathology, 118: 401-10.

Emechebe, A. M. and S. T. O. Lagoke. 2003. Recent advances in research on cowpea diseases Cowpea Integrated Pest Management. The International
Institute of Tropical Agriculture. Oyo State, Nigeria.

Fery, R. L. and P. D. Dukes. 1977. An assessment of two genes for Cercospora leaf spot resistance in the southern pea (Vigna unguiculata (L.) Walp.). HortScience, 12: 454-56.

Fery, R. L., P. D. Dukes and F. P. Cuthbert Jr. 1976. The inheritance of Cercospora leaf spot resistance in southernpea (Vigna unguiculata (L.) Walp.). Journal of the American Society for Horticultural Science, 101: 148-49.

Hayat, R., S. Ali, M. T. Siddique and T. H. Chatha. 2008. Biological nitrogen fixation of summer legumes and their residual effects on subsequent rainfed wheat yield. Pakistan Journal of Botany, 40: 711-22.

Jackson, J. C. 2009. Protein nutritional quality of cowpea and navy bean residue fractions. African Journal of Food, Agriculture, Nutrition and Development, 9: 
334-41.

Khan, A., A. Bari, S. Khan, N. S. Hussain and I. Zada. 2010. Performance of cowpea genotypes at higher altitude of NWFP. Pakistan Journal of Botany, 42: 2291-96.

Qamar, I. A., M. Noor and S. N. Mirza. 1993. A study of various genetic parameters in forage peas. Pakistan Journal of Agricultural Research, 14: 198-203.

Sabaghnia, N., H. Dehghani and S. H. Sabaghpour. 2006. Nonparametric methods for interpreting genotype $\mathrm{x}$ environment interaction of lentil genotypes. Crop Science, 46: 1100-06.
Sebetha, E. T., V. I. Ayodele, F. R. Kutu and I. K. Mariga. 2010. Yields and protein content of two cowpea varieties grown under different production practices in Limpopo province, South Africa. African Journal of Biotechnology, 9: 628-34.

Sinsiri, N., S. Loahasiriwong, S. Jogloy, B. Toomsan and W. Saksirirut. 2006. A Varietal Screening of Cowpea Cultivars (Vigna unguiculata) for a High Resistance to Pseudocercospora cruenta (Sacc.) Deighton in Northeast Thailand. Pakistan Journal of Biological Sciences, 9: 641-48. 